\title{
SUMBER YURIDIS PENDIDIKAN PANCASILA
}

\author{
ALVIRA ROSAYANTI \\ ryalvira@gmail.com \\ 20220050 \\ STIE AKBP KBP PADANG
}

\section{A. PENDAhuluan}

Indonesia yang berdasar pada Pancasila dan UUD Negara Republik Indonesia tahun 1945; mengaktualisasikan nilai-nilai Pancasila dalam bentuk pribadi yang saleh secara individual, sosial dan alam; memahami dan menganalisis dinamika Pancasila secara historis; mempresentasikan dinamika Pancasila secara historis, serta merefleksikan fungsi dan kedudukan penting Pancasila dalam perkembangan Indonesia mendatang. Bab ketiga membahas kedudukan Pancasila sebagai dasar negara. Pokok bahasan ini mengkaji hubungan antara Pancasila dan Proklamasi, hubungan antara Pancasila dan Pembukaan UUD Negara Republik Indonesia tahun 1945, penjabaran Pancasila dalam pasal-pasal UUD Negara Republik Indonesia tahun 1945, implementasi Pancasila dalam pembuatan kebijakan negara, khususnya dalam bidang politik, ekonomi, sosial budaya dan hankam. Pada bab ini, mahasiswa diajak untuk memahami konsep, hakikat, dan pentingnya Pancasila sebagai dasar negara, ideologi negara, atau dasar filsafat negara Republik Indonesia dalam kehidupan bernegara. Hal tersebut penting mengingat peraturan perundang-undangan yang mengatur organisasi negara, mekanisme penyelenggaraan negara, hubungan warga negara dengan negara, yang semuanya itu harus sesuai dengan nilai-nilai Pancasila. Mahasiswa diajak untuk mengetahui dan membahas bahwa Pancasila sebagai dasar negara yang autentik termaktub dalam Pembukaan UUD 1945. Inti esensi nilai-nilai Pancasila tersebut, yaitu ketuhanan, kemanusiaan, persatuan, kerakyatan, dan keadilan sosial. Bangsa Indonesia semestinya telah dapat mewujudkan keadilan sosial bagi seluruh rakyat Indonesia sebagaimana yang dicitacitakan, tetapi dalam kenyataannya belum sesuai dengan harapan. Hal tersebut merupakan tantangan bagi generasi muda, khususnya mahasiswa sebagai kaum intelektual, untuk berpartisipasi berjuang mewujudkan tujuan negara berdasarkan Pancasila. Agar partisipasi mahasiswa di masa yang akan datang efektif, maka perlu perluasan dan pendalaman wawasan akademik mengenai dasar negara melalui mata kuliah pendidikan Pancasila. Setelah mempelajari bab ini, mahasiswa diharapkan dapat menguasai kompetensi dasar; berkomitmen menjalankan ajaran agama dalam konteks Indonesia yang berdasar pada Pancasila dan Undang-Undang Dasar Negara Republik Indonesia tahun 1945; Sadar dan berkomitmen melaksanakan Pancasila, Undang-Undang Dasar Negara Republik Indonesia 
tahun 1945 dan ketentuan hukum di bawahnya, sebagai wujud kecintaannya pada tanah air; mengembangkan karakter Pancasilais yang teraktualisasi dalam sikap jujur, disiplin, tanggung jawab, peduli, santun, ramah lingkungan, gotong royong, cinta damai, responsif dan proaktif; bertanggung jawab atas keputusan yang diambil berdasar pada prinsip musyawarah dan mufakat; berkontribusi aktif dalam kehidupan berbangsa dan bernegara, berperan serta dalam pergaulan dunia dengan menjunjung tinggi penegakkan moral dan hukum; mengidentifikasi, mengkritisi, dan mengevaluasi peraturan perundang- undangan dan kebijakan negara, baik yang bersifat idealis maupun praktis- pragmatis dalam perspektif Pancasila sebagai dasar negara. Pada bab keempat dibahas tentang kedudukan Pancasila sebagai ideologi negara. Pokok bahasan ini mengkaji Pengertian dan Sejarah Ideologi, Pancasila dan Ideologi Dunia, Pancasila dan Agama. Bahasan ini sangat penting karena ideologi merupakan seperangkat sistem yang diyakini setiap warga negara dalam kehidupan bermasyarakat, berbangsa, dan bernegara. Mahasiswa tentu mengetahui bahwa setiap sistem keyakinan itu terbentuk melalui suatu proses yang panjang karena ideologi melibatkan berbagai sumber, seperti: kebudayaan, agama, dan pemikiran para tokoh. Ideologiyang bersumber dari kebudayaan, artinya, berbagai komponen budaya yang meliputi: sistem religi dan upacara keagamaan, sistem dan organisasi kemasyarakatan, sistem pengetahuan, bahasa, kesenian, sistem mata pencaharian hidup, sistem teknologi dan peralatan memengaruhi dan berperan dalam membentuk ideologi suatu bangsa. Mahasiswa perlu mengetahui bahwa ketika suatu ideologi bertitik tolak dari komponen- komponen budaya yang berasal dari sifat dasar bangsa itu sendiri, maka pelaku-pelaku ideologi, yakni warga negara, lebih mudah melaksanakannya. Para pelaku ideologi merasa sudah akrab, tidak asing lagi dengan nilainilai yang terdapat dalam ideologi yang diperkenalkan dan diajukan kepada mereka. Mahasiswa diajak untuk mengetahui bahwa agama juga dapat menjadi sumber bagi suatu ideologi. Di saat ideologi bersumber dari agama, maka akan ditemukan suatu bentuk negara teokrasi, yakni sistem pemerintahan negara yang berlandaskan pada nilai-nilai agama tertentu. Adapun ideologi yang bersumber dari pemikiran para tokoh, seperti marxisme. Marxisme termasuk salah satu di antara aliran ideologi (mainstream) yang berasal dari pemikiran tokoh atau filsuf Karl Marx 


\section{B. PEMBAHASAAN}

\section{Sumber Yuridis Pendidikan Pancasila}

Negara RI adalah negara hukum rechtsstaat dan salah satu cirinya atauistilah yang bernuansa bersinonim yaitu pemerintahan berdasarkan hukum rule of law. Pancasila sebagai Dasar Negara merupakan landasan dan sumber dalam membentuk dan menyelenggarakan negara hukum tersebut. Hal tersebut berarti pendekatan yuridis hukum merupakan salah satu pendekatan utama dalam pengembangan atau pengayaan materi mata kuliah pendidikan Pancasila. Urgensi pendekatan yuridis ini adalah dalam rangka menegakkan undang-undang law enforcement yang merupakan salah satu kewajiban negara yang penting. Penegakkan hukum ini hanya akan efektif apabila didukung oleh kesadaran hukum warga negara terutama dari kalangan intelektualnya. Dengan demikian, pada gilirannya melalui pendekatan yuridis tersebut mahasiswa dapat berperan serta dalam mewujudkan negara hukum formil dan sekaligus negara hukum materil, sehingga dapat diwujudkan keteraturan sosial social order dan sekaligus 22 terbangun suatu kondisi bagi terwujudnya peningkatan kesejahteraan rakyat, sebagaimana yang dicita-citakan oleh para pendiri bangsa. Aktivitas: Anda dipersilakan untuk mendiskusikan dengan teman sekelompok Anda tentang faktor penghambat dan penunjang diberlakukannya Pendidikan Pancasila di Perguruan Tinggi. Kemudian membuat laporan tertulis untuk diserahkan kepada dosen.

\section{Sumber Politik Pendidikan Pancasila}

Salah satu sumber pengayaan materi Pendidikan Pancasila adalah berasal dari fenomena kehidupan politik bangsa kita. Tujuannya agar Anda mampu mendiagnosa dan mampu memformulasikan saran-saran mengenai bagaimana mewujudkan kehidupan politik yang ideal sesuai dengan nilai-nilai Pancasila. Bukankah Pancasila dalam tataran tertentu merupakan ideologi politik yaitu mengandung nilai-nilai yang menjadi kaidah penuntun dalam mewujudkan tata tertib sosial politik yang ideal. Hal tersebut sejalan dengan pendapat Budiardjo 1998:32 yakni: Ideologi politik adalah himpunan nilai-nilai, idée, norma-norma, kepercayaan dan keyakinan, suatu "Weltanschauung", yang dimiliki seseorang atau sekelompok orang, atas dasar mana dia menentukan sikapnya terhadap kejadian dan problema politik yang dihadapinya dan yang menentukan tingkah laku politiknya. Melalui pendekatan politik ini Anda diharapkan mampu menafsirkan fenomena politik dalam rangka menemukan pedoman yang bersifat moral yang sesuai dengan nilai-nilai Pancasila untuk mewujudkan kehidupan politik yang sehat. Pada gilirannya Anda akan mampu memberikan kontribusi konstruktif dalam menciptakan struktur politik yang stabil dan dinamis. Secara spesifik fokus telaahan melalui pendekatan politik tersebut yaitu menemukan nilai-nilai ideal yang menjadi kaidah penuntun atau pedoman dalam mengkaji konsep-konsep pokok dalam politik yang meliputi negara state, kekuasaan power, pengambilan keputusan decision making, 
kebijakan policy, dan pembagian distribution sumber daya Negara, baik di pusat maupun di 23 daerah. Melalui kajian tersebut, Anda diharapkan lebih termotivasi berpartisipasi memberikan masukan konstruktif baik kepada infrastruktur politik maupun suprastruktur politik.

\section{c. Landasan Yuridis}

Landasan yuridis merupakan pertimbangan atau alasan yang menggambarkan bahwa peraturan yang dibentuk untuk mengatasi permasalahan hukum atau mengisi kekosongan hukum dengan mempertimbangkan aturan yang telah ada, yang akan diubah, atau yang akan dicabut guna menjamin kepastian hukum dan rasa keadilan masyarakat. Landasan yuridis menyangkut persoalan hukum yang berkaitan dengan substansi atau materi yang diatur sehingga perlu dibentuk Peraturan Perundang-Undangan yang baru. Beberapa persoalan hukum itu, antara lain, peraturan yang sudah ketinggalan, peraturan yang tidak harmonis atau tumpang tindih, jenis peraturan yang lebih rendah dari Undang-Undang sehingga daya berlakunya lemah, peraturannya sudah ada tetapi tidak memadai, atau peraturannya memang sama sekali belum ada.

Landasan yuridis dimuat dalam pokok pikiran pada konsiderans Undang-Undang, Peraturan Daerah Provinsi, atau Peraturan Daerah Kabupaten/Kota. Unsur yuridis menggambarkan bahwa peraturan yang dibentuk untuk mengatasi permasalahan hukum atau mengisi kekosongan hukum dengan mempertimbangkan aturan yang telah ada, yang akan diubah, atau yang akan dicabut guna menjamin kepastian hukum dan rasa keadilan masyarakat.

\section{PENUTUP}

Mata kuliah pendidikan Pancasila merupakan usaha sadar dan terencana untuk mewujudkan suasana belajar dan proses pembelajaran agar mahasiswa secara aktif mengembangkan potensi dirinya untuk memiliki pengetahuan, kepribadian, dan keahlian, sesuai dengan program studinya masing-masing. Selain itu, mahasiswa diharapkan mampu memberikan kontribusi yang konstruktif dalam bermasyarakat, berbangsa, dan bernegara, dengan mengacu kepada nilai-nilai Pancasila. Jadi, mata kuliah Pancasila merupakan proses pembelajaran dengan menggunakan pendekatan student centered learning, untuk mengembangkan knowledge, attitude, dan skill mahasiswa sebagai calon pemimpin bangsa dalam membangun jiwa profesionalitasnya sesuai dengan program studinya masing-masing dengan menjadikan nilai-nilai Pancasila sebagai kaidah 
penuntun (guiding principle) sehingga menjadi warga negara yang baik (good citizenship).

Pentingnya Mata Kuliah Pendidikan Pancasila Urgensi pendidikan Pancasila, yaitu dapat memperkokoh jiwa kebangsaan mahasiswa sehingga menjadi dorongan pokok (leitmotive) dan bintang penunjuk jalan (leitstar) bagi calon pemegang tongkat estafet kepemimpinan bangsa di berbagai bidang dan tingkatan. Selain itu, agar calon pemegang tongkat estafet kepemimpinan bangsa tidak mudah terpengaruh oleh paham-paham asing yang dapat mendorong untuk tidak dijalankannya nilai-nilai Pancasila. Pentingnya pendidikan Pancasila di perguruan tinggi adalah untuk menjawab tantangan dunia dengan mempersiapkan warga negara yang mempunyai pengetahuan, pemahaman, penghargaan, penghayatan, komitmen, dan pola pengamalan Pancasila. Hal tersebut ditujukan untuk melahirkan lulusan yang menjadi kekuatan inti pembangunan dan pemegang estafet kepemimpinan bangsa dalam setiap tingkatan lembaga-lembaga negara, badan-badan negara, lembaga daerah, lembaga infrastruktur politik, lembaga- 39 lembaga bisnis, dan profesi lainnya yang menjunjung tinggi nilai-nilai Pancasila. G. Tugas Belajar Lanjut: Mari Belajar Pancasila Untuk memahami Pancasila secara utuh dan mengetahui landasanlandasan dalam pendidikan Pancasila, Anda diharapkan dapat mencari informasi dari berbagai sumber tentang: 1. ketentuan undang-undang yang mengatur tentang pendidikan Pancasila lengkap dengan bunyinya. 2. fenomena sosial yang menunjukkan urgensi penyelenggaraan mata kuliah pendidikan Pancasila di perguruan tinggi Tugas selanjutnya, yaitu Anda melakukan survei terbatas kepada mahasiswa tentang tingkat pemahaman dan penghayatan nilai-nilai Pancasila sebagai ideologi bangsa di kalangan mahasiswa dan tentang persepsi mahasiswa mengenai tingkat kesadaran nilai-nilai Pancasila para elit politik, pengusaha, dan warga negara, khususnya generasi muda dewasa ini.

\section{DAFTAR PUSTAKA}

Darmini Roza dan Laurensius Arliman S Peran Pemerintah Daerah Di Dalam Melindungi Hak Anak Di Indonesia, Masalah-Masalah Hukum, Volume 47, Nomor 1, 2018.

Laurensius Arliman S, Komnas HAM dan Perlindungan Anak Pelaku Tindak Pidana, Deepublish, Yogyakarta, 2015.

Laurensius Arliman S, Penguatan Perlindungan Anak Dari Tindakan Human Trafficking Di Daerah Perbatasan Indonesia, Jurnal Selat, Volume 4, Nomor 1, 2016.

Laurensius Arliman S, Problematika Dan Solusi Pemenuhan Perlindungan Hak Anak Sebagai Tersangka Tindak Pidana Di Satlantas Polresta Pariaman, Justicia Islamica, Volume 13, Nomor 2, 2016. 
Laurensius Arliman S, Pelaksanaan Perlindungan Anak Yang Tereksploitasi Secara Ekonomi Oleh Pemerintah Kota Padang, Veritas et Justitia, Volume 2, Nomor 1, 2016.

Laurensius Arliman S, Kedudukan Ketetapan MPR Dalam Hierarki Peraturan Perundang-Undangan Di Indonesia,Lex Jurnalica, Volume 13, Nomor 3, 2016.

Laurensius Arliman S, Komnas Perempuan Sebagai State Auxialiary Bodies Dalam Penegakan Ham Perempuan Indonesia, Justicia Islamica, Volume 14, Nomor 2, 2017.

Laurensius Arliman S, Peranan Pers Untuk Mewujudkan Perlindungan Anak Berkelanjutan Di Indonesia, Jurnal Ilmu Hukum Tambun Bungai, Volume 2, Nomor 2, 2017.

Laurensius Arliman S, Mewujudkan Penegakan Hukum Yang Baik Untuk Mewujudkan Indonesia Sebagai Negara Hukum, Jurnal Hukum Doctrinal, Volume 2, Nomor 2, 2017.

Laurensius Arliman S, Participation Non-Governmental Organization In Protecting Child Rights In The Area Of Social Conflict, The 1st Ushuluddin and Islamic Thought International Conference (Usicon), Volume 1, 2017.

Laurensius Arliman S, Partisipasi Masyarakat Dalam Pembentukan Perundang Undangan Untuk Mewujudkan Negara Kesejahteraan Indonesia, Jurnal Politik Pemerintahan Dharma Praja, Volume 10, Nomor 1, 2017, https://doi.org/10.33701/jppdp.v10i1.379.

Laurensius Arliman S, Peran Komisi Perlindungan Anak Indonesia Untuk Mewujudkan Perlindungan Anak, Jurnal Respublica Volume 17, Nomor 2, 2018.

Laurensius Arliman S, Menjerat Pelaku Penyuruh Pengrusakan Barang Milik Orang Lain Dengan Mempertimbangkan Asas Fungsi Sosial, Jurnal Gagasan Hukum, Volume 1,Nomor 1, 2019.

Laurensius Arliman S, Ilmu Perundang-Undangan Yang Baik Untuk Negara Indonesia, Deepublish, Yogyakarta, 2019.

Laurensius Arliman S, Isdal Veri, Gustiwarni, Elfitrayenti, AdeSakurawati, Yasri, Pengaruh Karakteristik Individu, Perlindungan Hak Perempuan Terhadap Kualitas Pelayanan Komnas Perempuan Dengan Kompetensi Sumber Daya Manusia Sebagai Variabel Mediasi, Jurnal Menara Ekonomi: Penelitian dan Kajian Ilmiah Bidang Ekonomi, Volume 6, Nomor 2, 2020.

Laurensius Arliman S, Pendidikan Kewarganegaraan, Deepublish, Yogyakarta, 2020. 
Laurensius Arliman S, Makna Keuangan Negara Dalam Pasal Pasal 23 E Undang-Undang Dasar 1945, Jurnal Lex Librum, Volume 6, Nomor 2 Juni 2020, http://dx.doi.org/10.46839/1ljih.v6i2.151.

Laurensius Arliman S, Kedudukan Lembaga Negara Independen Di Indonesia Untuk Mencapai Tujuan Negara Hukum, Kertha Semaya Journal Ilmu Hukum, Volume 8, Nomor 7, 2020.

Laurensius Arliman S, Pelaksanaan Assesment Oleh Polres Kepulauan Mentawai Sebagai Bentuk Pelaksanaan Rehabilitasi Bagi Pecandu Dan Korban Penyalahgunaan Narkotika, Jurnal Muhakkamah, Volume 5, Nomor 1, 2020.

Laurensius Arliman S, Aswandi Aswandi, Firgi Nurdiansyah, Laxmy Defilah, Nova Sari Yudistia, Ni Putu Eka, Viona Putri, Zakia Zakia, Ernita Arief, Prinsip, Mekanisme Dan Bentuk Pelayanan Informasi Kepada Publik Oleh Direktorat Jenderal Pajak, Volume 17, No Nomor, 2020.

Larensius Arliman S, Koordinasi PT. Pegadaian (Persero) Dengan Direktorat Reserse Narkoba Polda Sumbar Dalam Penimbangan Barang Bukti Penyalahgunaan Narkotika, UIR Law Review, Volume 4, Nomor 2, 2020, https://doi.org/10.25299/uirlrev.2020.vol4(1).3779.

Laurensius Arliman S, Tantangan Pendidikan Kewarganegaraan Pada Revolusi 4.0, Ensiklopedia Sosial Review, Volume 2, Nomor 3, 2020.

Muhammad Afif dan Laurensius Arliman S, Protection Of Children's Rights Of The Islamic And Constitutional Law Perspective Of The Republic Of Indonesia, Proceeding: Internasional Conference On Humanity, Law And Sharia (Ichlash), Volume 1, Nomor 2, 2020.

Otong Rosadi danLaurensius Arliman S, Urgensi Pengaturan Badan Pembinaan Idelogi Pancasila Berdasarkan UndangUndang Sebagai State Auxiliary Bodies yang Merawat Pancasila dalam Perspektif Hak Asasi Manusia, Prosiding Konferensi Nasional Hak Asasi Manusia, Kebudayaan dan Tujuan Pembangunan Berkelanjutan Indonesia pada Masa Pandemi Covid-19: Tantangan untuk Keilmuan Hukum dan Sosial Volume 1, Universitas Pancasila, Jakarta, 2020. 